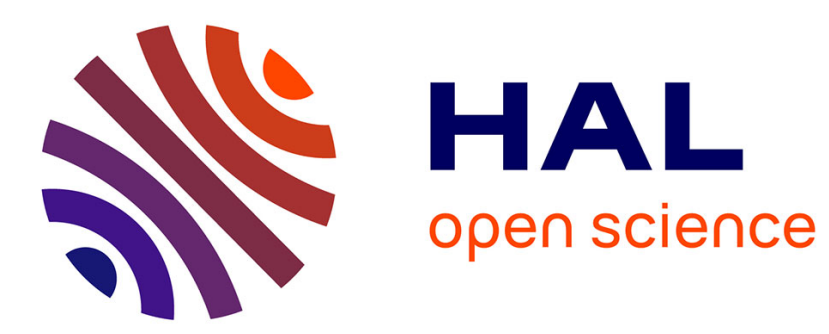

\title{
Suitable conditions for detecting apple chlorotic leaf spot virus in apricot trees by enzyme-linked immunosorbent assay (ELISA)
}

Gerardo Llacer, Mariano Cambra, Amparo Lavina, José Aramburu

\section{- To cite this version:}

Gerardo Llacer, Mariano Cambra, Amparo Lavina, José Aramburu. Suitable conditions for detecting apple chlorotic leaf spot virus in apricot trees by enzyme-linked immunosorbent assay (ELISA).

Agronomie, 1985, 5 (9), pp.809-812. hal-00884815

\section{HAL Id: hal-00884815 https://hal.science/hal-00884815}

Submitted on 1 Jan 1985

HAL is a multi-disciplinary open access archive for the deposit and dissemination of scientific research documents, whether they are published or not. The documents may come from teaching and research institutions in France or abroad, or from public or private research centers.
L'archive ouverte pluridisciplinaire HAL, est destinée au dépôt et à la diffusion de documents scientifiques de niveau recherche, publiés ou non, émanant des établissements d'enseignement et de recherche français ou étrangers, des laboratoires publics ou privés. 


\section{Suitable conditions for detecting apple chloro- tic leaf spot virus in apricot trees by enzyme- linked immunosorbent assay (ELISA)}

Gerardo LLACER, Mariano CAMBRA, Amparo LAVINA \& José ARAMBURU

Instituto Valenciano de Investigaciones Agrarias, Departamento de Protección Vegetal, Apartado Oficial, Moncada (Valencia), España

Apple chlorotic leaf spot virus (CLSV) occurs irregularly within infected apricot trees and this causes difficulties in detecting it. This work aimed at studying the most adequate sampling time and suitable parts of the plant for a reliable detection of CLSV in apricot, using the enzyme-linked immunosorbent assay (ELISA) technique. Detection was most reliable on fruits, in spring, any time during their development. The results obtained with this method provided some evidence against the claimed association between CLSV and "viruela" disease (apricot pox).

Additional key words : Virus translocation, "viruela” disease, apricot pox.

Conditions appropriées à la détection du virus des taches foliaires chlorotiques du pommier chez l'abricotier au moyen de la technique immunoenzymatique ELISA.

Le virus des taches foliaires chlorotiques du pommier (CLSV) est distribué irrégulièrement dans les abricotiers infectés, ce qui occasionne des problèmes pour sa détection. L'objectif poursuivi dans ce travail était la recherche des époques de prélèvement et des portions de la plante les plus appropriées pour une détection fiable du CLSV chez l'abricotier, au moyen de la technique immunoenzymatique ELISA. Le maximum de fiabilité se situe au printemps, en appliquant la technique aux fruits à n'importe quel moment de leur développement. Cette méthode de détection a fourni des arguments contraires à la prétendue association entre le CLSV et la "viruela " de l'abricotier.

Mots clés additionnels : Distribution du virus, "viruela » (variole) de l'abricotier.

\section{INTRODUCTION}

Apple chlorotic leaf spot virus (CLSV) occurs quite unevenly within infected apricot trees : it is absent in many buds during the grafting period, making it possible to obtain plants free of CLSV by budding them on apricot seedlings in summer (LLACER et al., 1983a). This irregular distribution is a major drawback in detecting the virus, since a negative result from the application of any detection method only indicates that the virus is absent (or in non-detectable amounts) at indexing time in that part of the plant sampled. The main objective of our work was to determine the most favourable sampling time and the best parts of the plant to be used for a reliable detection of CLSV in apricot, by using the enzyme- linked immunosorbent assay (ELISA) technique. This technique has been already used by FLEGG \& CLARK (1979), DetIENNe et al. (1980) and Pracros et al. (1981) for detecting different strains of CLSV.

Years ago PEÑA-IGLESIAS \& AYUSO (1973) found that CLSV was the only virus present on all apricot trees showing symptoms of "viruela" (apricot pox disease). These trees were tested by graft-transmission on "GF-305" peach seedlings. These results lead these researchers to believe that CLSV was the cause of "viruela" in "Búlida" and "Galta Roja" apricots and this has been accepted ever since, although Koch's postulates were never proved. The availability of a highly reliable method for detecting CLSV in apricot allowed us to approach a second objective of our work: to verify the claimed CLSV-"viruela" association. 


\section{MATERIALS AND METHODS}

To establish the optimum sampling time and parts of the plant to be sampled for reliable detection of CLSV in apricot, two "Búlida" trees, grown in large containers in a screenhouse and infected with CLSV by grafting in 1978, were used. These two "Búlida", trees, grafted on apricot seedlings, were originated in a clonal selection of "Búlida" apricots from the Murcia region and were previously described by LLACER et al. $(1983 a)$. In summer 1983, 88 buds were randomly collected from each tree as indicated in figure 1 ( 8 budsticks per tree and 11 buds per budstick). During winter 1983-84, a similar operation was performed in the same trees by taking 84 buds per plant, distributed on 6 budsticks (fig. 1) : 2 short budsticks (4-6 buds long), 2 long ones (more than 25 buds long) and 2 intermediate budsticks (14-17 buds long). This operation was aimed at determining whether the length of the budsticks had an influence on CLSV distribution, as reported to occur in apple (FRIDLUND, 1982).

In spring 1984, again from the same trees, 16 young shoots per tree were randomly collected and also 16 fruits, each one adjacent to one of the shoots. At that time, late April, the fruits were still very small, 4 to $10 \mathrm{~g}$.

Assessment of presence of CLSV on buds, shoots, leaves and fruits was done by the enzyme-linked immunosorbent assay (ELISA), as previously described by CAMBRA et al. (1982 and 1983). The CLSV antiserum had been prepared against the bark split (P-863) strain (DETIENNE et al., 1980). It was kindly provided by Dr. J. Dunez (Station de Pathologie Végétale, I.N.R.A., Bordeaux, France). Purification of immunoglobulins (Ig) and their conjugation with alkaline phosphatase (Ig-E) was done following CAMBRA et al. (1983). The microplates (NUNCImmunoplate I) were coated with $2 \mu \mathrm{g} / \mathrm{ml} \mathrm{Ig}$ and the conjugate Ig-E was diluted 1/300. Bud, shoot, leaf and fruit samples were thinly sliced and ground with Kinematica Polytron homogenizer. The extraction medium consisted of phosphate buffer (PBS) with $2 \%$ polyvinyl pyrrolidone (PVP) and supplemented with $2.5 \%$ nicotine, as recommended by DETIENNE $e t$ al. (1980) and CAMBRA et al. (1982). Ratios of 1/10 or $1 / 20$ ( $\mathrm{g}$ of tissue $/ \mathrm{ml}$ extracting medium) were used. For comparison between shoots and fruits, equal ratios were always taken. The optical density (OD) values were obtained by measuring at $405 \mathrm{~nm}$.

To check the CLSV-"viruela" association in apricot, the ELISA technique was applied to mature fruits of 32 "Búlida" or "Galta Roja" trees in June 1984. The 32 trees were grafted on apricot seedlings and presented clear symptoms of "viruela" (fig. 2). Between 8 to 24 fruits per tree (sets of 4 fruits) were analysed but, in some cases, up to 60 fruits per tree (20 sets, 3 fruits each) were used. The samples were always randomly collected.

\section{RESULTS AND DISCUSSION}

Figure 3 shows the number and location of the buds infected with CLSV over the different seasons studied. In summer the virus was detected on only
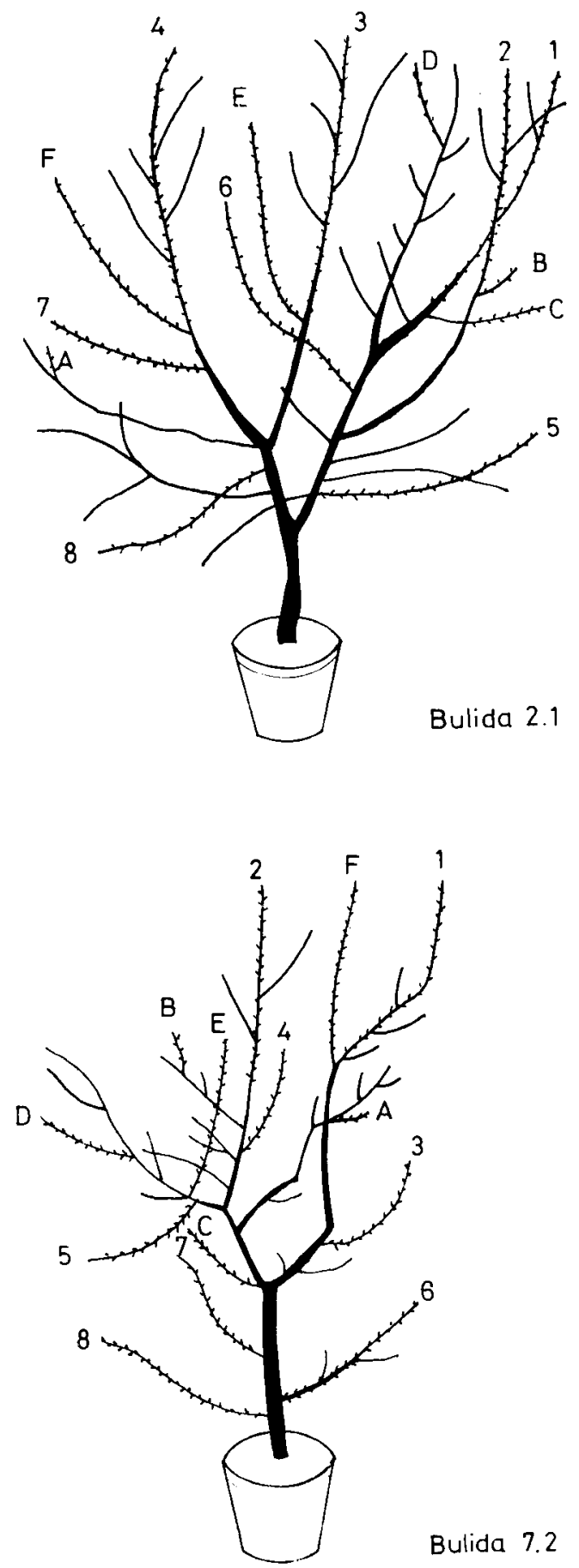

Bulida 7.2

Figure 1

Distribution of the budsticks used in summer, 1983 (1-8) and winter, 1983-84 (A-F) for CLSV detection by ELISA in buds of two "Búlida" apricots.

Distribution des rameaux utilisés en été 1983 (1-8) et en hiver 1983-84 (A-F) pour la détection par ELISA du CLSV sur des bourgeons de deux abricotiers « Búlida».

$2 \%$ of the buds from one tree and $33 \%$ from the other one. This result is consistent with the ease with which CLSV-free plants of "Búlida" apricot can be obtained by summer budding on apricot seedlings (LLACER et al., 1983a). Examination of figure 3 (upper part) does not establish any basis for predicting the summer distribution of CLSV on an apricot tree; the only fact observed was that virus distribution was more irregular within the tree than within each budstick. 

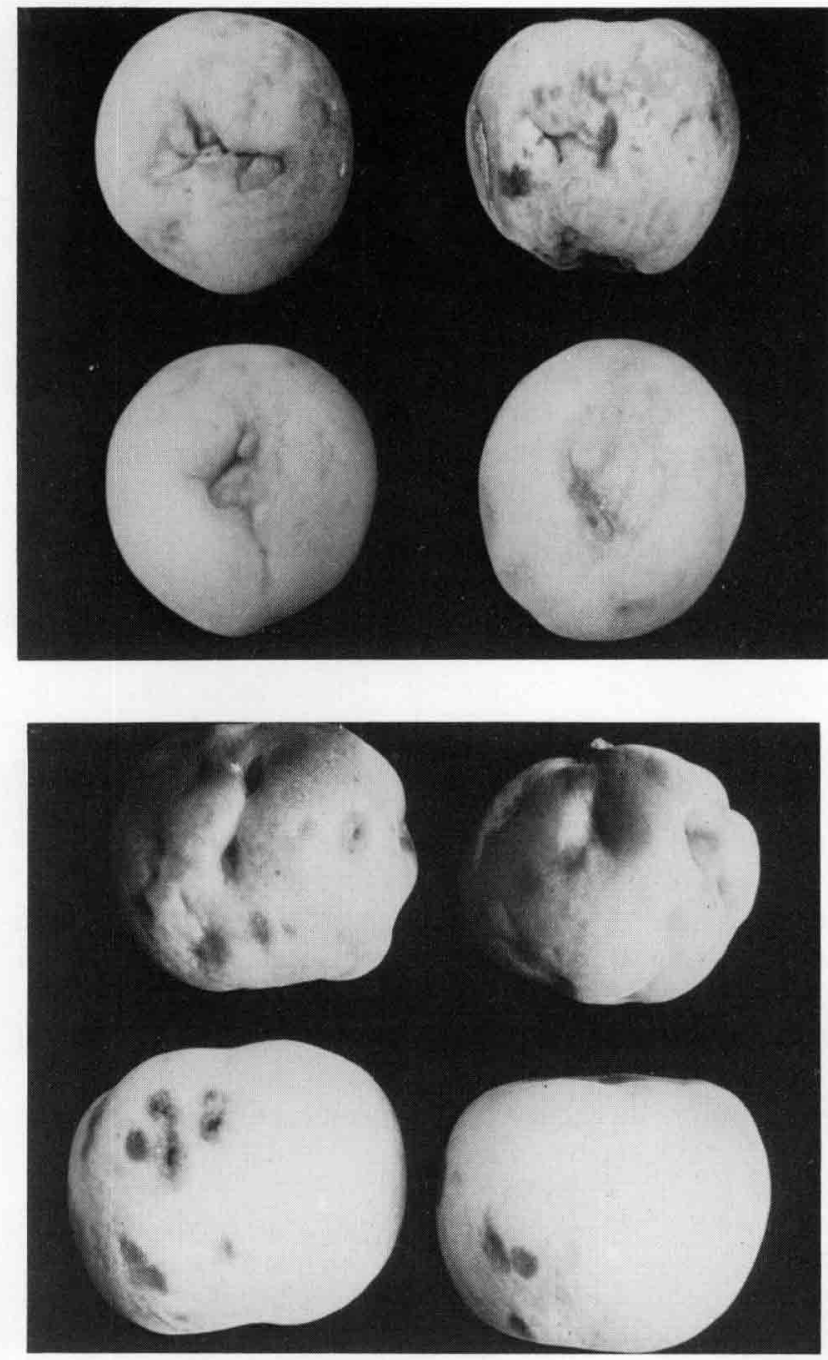

Figure 2

"Viruela" symptoms on "Búlida" (above) and "Galta Roja" (below) apricot fruits.

Symptômes de "viruela » sur fruits d'abricotier «Búlida» (en haut) et "Galta Roja" (en bas).

Over the winter dormant season, CLSV was detected on $30 \%$ and $85 \%$, respectively, of the tested buds. Detection was, therefore, quite reliable for "Búlida" 7.2 (fig. 3, lower part) during that period ; however, it continued to be unreliable for "Búlida" 2.1. The length of the budsticks in "Búlida" 2.1 had no influence on virus distribution.

The discrepancies observed between "Búlida" 2.1 and "Búlida" 7.2 can be explained by their different clonal origin. The ease with which CLSV-free plants could be obtained by summer budding on apricot seedlings was also different (LlACER et al., 1983a). The erratic distribution of CLSV in apricot trees is not a unique feature of this virus. A similar condition is present in different viruses and hosts, e.g., plum pox virus in peach (MORVAN \& CASTELAIN, 1976) and cherry leaf roll virus in walnut (DELBOS et al., 1984).

During spring, CLSV was detected in both trees on $100 \%$ of young shoots or fruits tested. Optical density (OD) values obtained by ELISA from fruits were higher than those obtained from shoots. In late April, the average OD values measured at $30 \mathrm{mn}$ were
Summer 1983

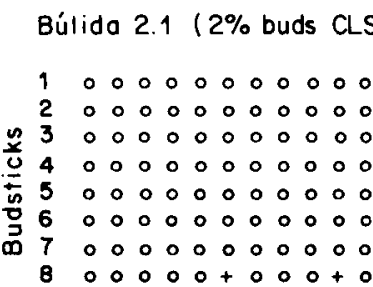

Búlida $7.2(33 \%$ buds CLSV+)

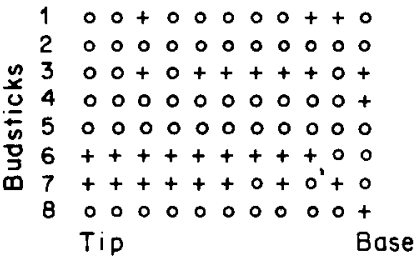

Winter 1983-84

Búlida $2.1(30 \%$ buds CLSV+)

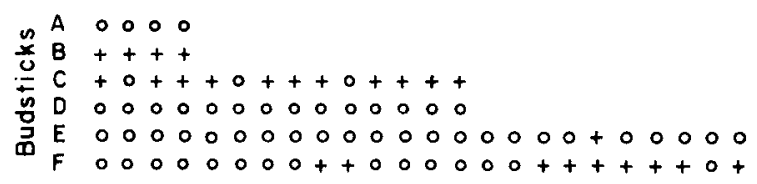

Búlida 7.2 ( $85 \%$ buds CLSV+)

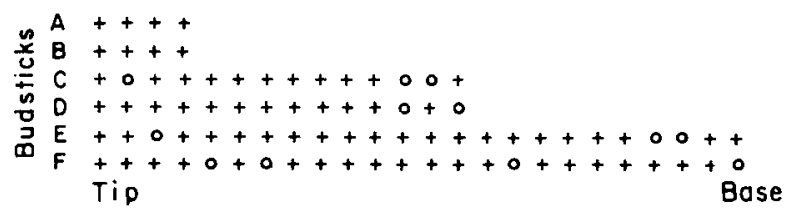

Figure 3

Number and location of the "Búlida" buds infected (+) or not infected (0) by CLSV during the two periods studied.

Nombre et emplacement des bourgeons de «Búlida infectés (+) ou non infectés (0) par CLSV pendant les deux périodes étudiées.

0.909 in fruits and 0.595 in shoot extracts. OD values obtained with fruit extracts increased as the fruits grew and matured whereas OD values with shoot and leaf extracts decreased from April to the end of the summer, according to several surveys conducted to determine the health status of native apricots from Murcia and Valencia (unpublished data). The higher virus concentration in fruits or the greater ease of virus extraction allowed the use of higher dilutions of the conjugate (up to threefold) in the immuno-enzymatic assay, providing a considerable saving in detection work.

Summarizing, CLSV behaviour in apricot contrasted with that in peach where the virus could be reliably detected in any season (CAMBRA et al., 1982). Maximum reliability in detecting CLSV by ELISA in apricot was obtained in spring and early summer, when some fruits still remained on the tree. CLSV was detected in fruits irrespective of the presence of symptoms on them. By mid-summer, test reliability was minimum, using either buds or leaves. During that season, CLSV-free plants could easily be 
obtained by budding on apricot seedlings. Detection of CLSV during the winter dormant season was more reliable than in summer ; however, a negative result in that period did not guarantee absence of virus in the plant either. In trees too young or too heavily pruned to bear fruit (young trees or plants from multiplication stock in nurseries), detection was most reliable in spring, on young shoots.

Finally, the application of the ELISA technique to mature fruits collected from 32 apricot trees showing "viruela" symptoms provided some evidence against the claimed CLSV-"viruela" association : more than a half of these trees (17) gave negative results in detection assays for CLSV, whereas a positive ELISA reaction was obtained with all the fruits assayed from infected trees. The detection assay was repeated on 60 fruits per tree from 3 of the trees that had given negative results in the first assay. The result was consistently negative.

There seems to be a remote possibility that "viruela" was associated with a CLSV strain serologically different to that used to prepare the antiserum. With the same antiserum, DETIENNE et al. (1980) detected 9 different strains of CLSV (all the set tested) from 13 fruit tree species and we have detected CLSV in many apricot trees with "viruela" symptoms. If "viruela" were due to a different strain of CLSV, all these trees would be infected at the same time by two CLSV strains.

The apricot trees which gave negative ELISA results in our assay were not indexed for CLSV on peach seedlings or other indicator plants, but it has been shown previously (PRACROS et al., 1981 ; CAMBRA et al., 1982) that the ELISA technique has a higher detection efficiency for CLSV than indexing on "GF-305" peach seedlings.
The disagreement between our results and those reported by PEÑA-IGLESIAS \& AYUSO (1973) is probably due to the fact that most of the source trees used by them were grafted on "Pollizo" plum, whereas all our source trees were on apricot seedlings. "Pollizo" plum is the rootstock most currently used for apricot trees in Murcia and at present we know that it is practically $100 \%$ infected by CLSV (LLACER et al., 1983b).

We based our choice of trees grafted on apricot seedlings on our previous information that bud multiplication on apricot seedlings, in summer, provided many plants free of CLSV. In Murcia, 'Búlida" apricots grafted on apricot seedlings showed "viruela" symptoms just like those grafted on "Pollizo". In years with favourable conditions for the appearance of the disease, nearly all the trees showed some "viruela" symptoms. These facts lead us to postulate that "viruela" might be associated not with a virus disease, but rather to a genetic character of the "Búlida" and "Galta Roja" cultivars. One fact that cannot be discarded is that presence of CLSV increases the rate of fruits with symptoms, as reported to occur in "Golden Delicious" apple trees affected by russeting, another non-virus disease (MARENAUD \& LESPINASSE, 1970).

We have obtained some "Búlida" plants free of CLSV. When these plants begin to produce fruits, we shall have a final conclusion about the CLSV-“viruela" relation.
Cambra M., Llacer G., Perez de Sanroman C., 1982. Use of enzyme-linked immunosorbent assay (ELISA) for virus detection on stone fruit trees in Spain. Acta Hortic., 130 (1983), 145-150.

Cambra M., LLacer G., Perez de Sanroman C., Moreno P., Durba V., 1983. Diagnóstico rápido de virus en frutales de hueso mediante la técnica inmunoenzimática ELISA-DAS. Bol. Serv. Plagas, 9, 45-59.

Delbos R., Bonnet A., Dunez J., 1984. Le virus de l'enroulement des feuilles du cerisier, largement répandu en France sur noyer, estil à l'origine de l'incompatibilité de greffage du noyer Juglans regia sur Juglans nigra? Agronomie, 4 (4), 333-339.

Detienne G., Delbos R., Dunez J., 1980. Use and versatility of the immunoenzymatic ELISA procedure in the detection of different strains of an apple chlorotic leaf spot virus. Acta Phytopathol. Acad. Sci. Hung., 15, 39-45.

Flegg C. L., Clark M. F., 1979. The detection of apple chlorotic leaf spot virus by a modified procedure of enzyme-linked immunosorbent assay (ELISA). Ann. appl. Biol., 91, 61-65.

Fridlund P. R., 1982. Distribution of chlorotic leaf spot virusinfected buds on various lengths of apple budsticks in successive years. Acta Hortic., 130 (1983), 85-88.
Llacer G., Cambra M., Martinez A., Martinez R., 1983a. Obtención de plantas seleccionadas de albaricoquero Búlida libres de "chlorotic leaf spot virus" (CLSV). $I^{\circ}$ Congr. Soc. Esp. Cienc. Hortic., Valencia, 633-640.

Llacer G., Cambra M., Rodriguez J., Laviña A., 1983b. Estado sanitario de melocotoneros autóctones de Murcia determinado mediante la técnica inmunoenzimática ELISA. $I^{\circ}$ Congr. Soc. Esp. Cienc. Hortic., Valencia, 641-648.

Marenaud C., Lespinasse J. M., 1970. Influence des virus latents sur le Russeting de Golden Delicious. CTIFL-Documents, 25, 1-3.

Morvan G., Castelain C., 1976. Localization of the sharka virus in peach trees in reference to sanitary checking. Mitt. Biol. Bundesanst. Land-Forstwirstsch. Berlin-Dahlem, H., 170, 65-72.

Peña-Iglesias A., Ayuso P., 1973. Preliminary identification of the viruses producing Spanish apricot pseudopox (viruela) and apricot mosaic diseases. Acta Hortic., 44 (1975), 255-265.

Pracros P., Detienne G., Sarraquigne C., Dunez J., 1981. Intérêts comparés de l'indexage biologique sur semis de pêcher GF-305 et du diagnostic immunoenzymatique ELISA pour la détection de virus des espèces fruitières. Agronomie, 1 (7), 535-540. 